\title{
Possibilidades textuais e gêneros discursivos
}

RuMoRes, revista científica online dedicada aos estudos de comunicação, linguagem e mídias, apresenta sua $11^{\text {a }}$ edição refletindo uma preocupação constante das pesquisas na área de comunicações e artes, voltada justamente para os limites entre as práticas comunicacionais e artísticas. Tal desafio de desenhar as fronteiras entre os campos, ou mesmo o debate sobre a necessidade mesma de fazê-lo, está também relacionado às discussões teóricas sobre as transposições entre os diversos gêneros discursivos.

Começamos pensando a importância da mídia no estabelecimento e circulação dos discursos sobre os direitos humanos, a cidadania e a sustentabilidade. Tal articulação temática tem gerado pautas e o artigo de Pedro Celso Campos preocupa-se em apontar como o debate público pode ser melhor informado, destacando inclusive nuances na apropriação midiática de conceitos. O tema se revela especialmente premente no bojo de grandes eventos nacionais e internacionais voltados à defesa de direitos, pensados por Elaine Cristina Gomes de Moraes e Murilo Cesar Soares enquanto estratégias de comunicação. E se lembrarmos que essa informação voltada para a cidadania circula comercialmente,como outras, o texto de Fábio Souza de Cruz e Marcelo Oliveira de Moura propõe que há de se ponderar sobre sua condição de mercadoria no entremeio da defesa dos direitos humanos e da existência de uma cultura da mídia.

O debate sobre a circulação de um discurso midiático específico associase ao imaginário da profissão de jornalista, indicando uma possível análise das práticas midiáticas. Em seu artigo, Mônica Martinez entende que as narrativas jornalísticas têm o efeito de um haicai, na estrutura textual concisa e sintética 
afinada ao que se demanda da escrita para o meio digital, discutindo as possibilidades de construção de textos objetivos. Observando o papel da memória no processo de construção de uma narrativa que tende à objetividade, Adriano de Paula Rabelo, por sua vez, analisa como o jornalismo e os jornalistas foram retratados pelo escritor Nelson Rodrigues. E se as memórias podem ser um dado desviante em relação ao narrar objetivo, o texto de Adélia Barroso Fernandes aponta para o papel da emoção como argumento no jornalismo, exemplificando especificamente com estratégias discursivas do jornal Folha de S. Paulo. Mariana Rezende dos Passos, em seu artigo, investiga as possibilidades de representarse a si mesmo nas redes sociais, ocupando-se do caso da presença nelas da então candidata Marina Silva, em campanha pela presidência da República.

Da investigação sobre possibilidades textuais e suas combinações desviantes passamos também asuas correspondentes aberturas para a leitura e a formação de novos leitores. No campo das mídias digitais, Raul Inácio Busarello, Patricia Bieging e Vânia Ribas Ulbricht observam o caso da nova tecnologia para games kinect como forma diferenciada de narrativa interativa, observando como pode se dar a imersão do corpo humano nesse ambiente, especialmente através do registro da voz.

Mas temos de ressaltar que a abertura para o diálogo intertextual e o trabalho na fronteira entre gêneros não se passa apenas no domínio estritamente comunicacional, mas tem encontrado nas pesquisas dedicadas à análise fílmica um campo profícuo. José Duarte nos traz as desventuras dos contos de viagem de Sullivan, categorizados como comédia, mas realiza um passeio audiovisual, através do protagonista, por diversos outros gêneros cinematográficos. Rodrigo Desider Fischer, por sua vez, relaciona a imagem do rosto humano fotogênico à criação de um vínculo afetivo na fruição do cinema de John Cassavetes. Um único quadro, no caso aquele da cena final de Zabriskie Point, é justamente o ponto de partida para a aproximação que Eduardo Harry Luersen faz entre cinema, música e pintura, procurando identificar a maestria de Michelangelo Antonioni em referenciar linguagens distintas. 
A investigação de novas formas narrativas, que se diferenciem da estrutura clássica, é tema do artigo de Marcelo Ikeda sobre os filmes-diários de Jonas Mekas, especialmente articulando memória e estética. A presença do ato ficcional na construção da imagem é também preocupação de Nicolas Llano ao observar a produção fotográfica de Jeff Wall, apresentando trabalho de construção e controle sobre ela. Se tratar de imaginário nos remete a pensar prioritariamente a condição da imagem, Ivan Vasconcelos Figueiredo abre a perspectiva para o trabalho de imaginários sociodiscursivos presentes num jornal visual para surdos.

Neste número, RuMoRes traz também as seções Entrevista, apresentando diálogo entre Flávio Augusto Queiroz e Silva e o filósofo francês Daniel Bougnoux sobre a validade do resgate de autores considerados clássicos para o debate teórico no campo da comunicação; e Ensaio, sobre as mudanças na configuração da família baiana contemporânea como influência para os hábitos de leitura e para a formação de leitores neste estado.

O debate se estende com a seção Resenhas, apresentando texto de Maria Noemi de Araújo sobre o livro n.d.a, de Arnaldo Antunes, que sonda as alternativas poéticas na escrita do autor. No sentido inverso, Rafael Duarte Oliveira Venancio e Eliza Bachega Casadei resenham a obra História da imprensa paulista: jornalismo e poder de D. Pedro I a Dilma, de Oscar Pilagallo, observando a forma da escrita da história da imprensa paulista através da relação entre fatos históricos e relatos midiáticos. Deslocando-se entre os diversos gêneros midiáticos, esperamos que os artigos aqui reunidos possam apontar para novas práticas narrativas e suas incessantes possibilidades de combinação.

Boa leitura!

Rosana de Lima Soares e Andrea Limberto

junho de 2012 